\title{
Incredulity Toward Metanarrative: Negotiating Postmodernism and Feminisms
}

\author{
Linda Hutcheon
}

\section{L'incrédulité envers des métanarratifs: \\ les négoces du post-modernisme et des féminismes}

Tant que les féminismes utilisent les stratégies parodiques postmodernes de la déconstruction, ils ne souffrent pas de la confusion du post-modernisme des programmes politiques (fait de rejeter et la droite et la gauche et d'être acceptés par les deux) en partieà cause de leur position qui offre diverses façons de comprendre les coutumes esthétiques et sociales à la lumière des relations entre les genres. Alors que les féminismes et le post-modernisme ont travailléà comprendreles modes dominants de représentation, les féminismes se sont concentrés sur le sujet férninin de la représentation et ils ont pressé le post-modernisme de reconsidérer ses défis antimétanarratifs pourl'universel humaniste en termes de genre.

It was conservative politics, it was subversive politics; it was the return of tradition, it was the final revolt of tradition; it was the unmooring of patriarchy, it was the reassertion of patriarchy.

- Anne Friedberg

When Jean-François Lyotard defined the postmodern condition as a state of incredulity toward metanarratives, ${ }^{1}$ he set the stage for a series of ongoing debates about the various narrative systems by which human society orders and gives meaning, unity, and 'universality' to its experience. Lyotard himself, in debate with the defender of the 'unfinished project' of modernity, Jürgen Habermas, ${ }^{2}$ took on what he saw as the dominant metanarratives of legitimation and emancipation, arguing that postmodernity is characterized by no grand totalizing master narrative but by smaller and multiple narratives which do not seek (or obtain) any universalizing stabilization or legitimation. Fredric Jameson ${ }^{3}$ has pointed out that both Lyotard 
and Habermas are really, in fact, working from 'master narrative' positions - one French and (1789) Revolutionary in inspiration and the other Germanic and Hegelian; one valuing commitment, the other consensus. Richard Rorty, ${ }^{4}$ in turn, has offered a trenchant critique of both positions, ironically noting that what they share is an almost overblown sense of the role of philosophy today.

Overblown or not, this issue of the role and function of metanarratives in our discourses of knowledge is one that demands our attention. Various forms of feminist theory and criticism have come at it from a particular angle: the metanarrative that has been their primary concern is obviously patriarchy, especially at its point of imbrication with the other major master narratives of our day-capitalism and liberal humanism. In their form of critique, feminisms ${ }^{5}$ have overlapped in concern with Marxist and poststructuralist theories and with what has been called postmodern art - art which is paradoxically both selfreflexive and historically grounded, both parodic and political: the paintings of Joanne Tod or Joyce Wieland, the fiction of Susan Swan or Jovette Marchessault, the photography of Geoff Miles or Evergon. Such art is ironic, not nostalgic in its engagement with history and with art history. It works to 'de-doxify' the 'doxa' - what Roland Barthes called public opinion or the 'Voice of Nature' and consensus. ${ }^{6}$ But there is a catch here: because of its use of irony as a strategic discursive device, postmodernism both inscribes and subverts its target. From its first manifestations in architecture to the present, postmodern art has juxtaposed and given equal value to the inward-directed world of art and the outward-directed world of history and experience. The tension between these apparent opposites finally defines the paradoxically 'worldly' 'texts' of postmodernism. In response to the question of metanarrative, postmodernism's stand is one of wanting to contest cultural dominants (patriarchy, capitalism, humanism, etc.) and yet knowing it cannot extricate itself completely from them: there is no position outside these metanarratives from which to launch a critique that is not in itself compromised. And this sparks, just as powerfully, the no less real, if ultimately inevitably compromised politics of the postmodern. Indeed it is their compromised stance which makes those politics recognizable and even familiar to us.

It is over this paradox of postmodernism's complicitous critique of metanarrative that feminisms and postmodernism part company. Of course, many commentators have recently pointed to the maleness of 
the modernist tradition, and therefore to the implied maleness of any postmodernism that is either in reaction to or even a conscious break from that modernism. Feminisms have been resisting incorporation into the postmodern camp, and with good reason: their political agendas would be endangered, or at least obscured by the double coding of that complicitous critique; their historical particularities and relative positionalities would risk being subsumed. Both enterprises work toward an awareness of the social nature of cultural activity, but feminisms are not content with exposition: art forms cannot change unless social practices do. Exposition may be the first step, but it cannot be the last. Nevertheless feminist and postmodern artists do share a view of art as a social sign inevitably and unavoidably enmeshed in other signs in systems of meaning and value. But I would argue that feminisms want to go beyond this to work to change those systems, not just to 'de-doxify' them.

But there is yet another difference between the two enterprises. Barbara Creed puts it this way:

Whereas feminism would attempt to explain that crisis [of legitimation that Lyotard has described] in terms of the workings of patriarchal ideology and the oppression of women and other minority groups, postmodernism looks to other possible causes - particularly the West's reliance on ideologies which posit universal truths - Humanism, History, Religion, Progress, etc. While feminism would argue that the common ideological position of all these 'truths' is that they are patriarchal, postmodern theory ... would be reluctant to isolate a singlemajor determining factor. ${ }^{7}$

'Reluctant to' because it cannot - not without falling into the trap of which it implicitly accuses other ideologies: that of totalization. Creed is right in saying that postmodernism offers no privileged, unproblematic position from which to speak. Therefore, she notes, ' $[t]$ he paradox in which we feminists find ourselves is that while we regard patriarchal discourses as fictions, we nevertheless proceed as if our position, based on a belief in the oppression of women, were somewhat closer to the truth. ${ }^{8}$ But postmodernism's rejection of a privileged position is as much an ideological stand as this feminist taking of a position. By ideology here, I mean that all-informing complex of social 
practices and systems of representation. The political confusion surrounding postmodernism - rejected and recuperated by both the left and the right-is not accidental, but a direct result of its double encoding as complicity and critique. While feminisms may use postmodern parodic strategies of deconstruction, they never suffer from this confusion of political agenda, partly because they have a position and a 'truth' that offer ways of understanding aesthetic and social practices in the light of the production of - and challenge to - gender relations. This is their metanarrative. This is also their strength and, in some people's eyes, their necessary limitation.

While feminisms and postmodernism have both worked to help us understand the dominant modes of representation at work in oursociety, feminisms have focussed on the specifically female subject of representation and have begun to suggest ways of challenging and changing those dominants in both mass culture and high art. They have taught us that to accept unquestioningly any fixed representations - in fiction, film, advertising or whatever - is to condone social systems of power which validate and authorize some images of women (or blacks, Asians, gays, etc.) and not others. Cultural production is carried on within a social context and an ideology-a lived value system - and it is to this that feminist work has made us pay attention. Feminisms have, in this way, had a very profound effect on postmodernism. It is not accidental that the postmodern coincides with the feminist re-evaluation of non-canonical forms of narrative discourse, that a very postmodern autobiography, Roland Barthes by Roland Barthes, and a very postmodern family biography, MichaelOndaatje's Running in the Family, have a lot in common with Christa Wolf's Patterns of Childhood or Daphne Marlatt's Ana Historic. They all not only challenge what we consider to be literature (or, rather, Literature) but also what was once assumed to be the seemless, unified narrative of representations of subjectivity in life-writing. Victor Burgin has claimed that he wants his photography and his art theory to show the meaning of sexual difference as a process of production, as 'something mutable, something historical, and therefore something we can do something about. ${ }^{9}$ Postmodernism cannot do that something, however; it can un-do but, without a metanarrative to direct its political agenda, that is all it can do.

Feminisms, on the other hand, can do more. For instance, in granting new and emphatic value to the notion of 'experience,' they have 
given a different angle on a very postmodern question: what constitutes a valid historical narrative? And who decides? This has led to the re-evaluation of personal or life narratives - journals, letters, confessions, biographies, autobiographies, self-portraits. In Catherine Stimpson's terms: 'Experiencegenerated more than art; it was a source of political engagement as well. ${ }^{10}$ If the personal is the political, then the traditional separation between private and public history must be rethought. This feminist rethinking has coincided with a general renegotiation of the separation of high art from the culture of everyday life - popular and mass culture - and the combined result has been a reconsideration of both the context of historical narrativeand the politics of representation and self-representation.

There is, in fact, a two-way involvement of the postmodern with the feminist: on theone hand, feminisms have successfully urged postmodernism to reconsider - in terms of gender - its anti-metanarrative challenges to that humanist 'universal' called 'Man' and have supported and reinforced its 'de-doxifying' of the separation between the private and the public, the personal and the political; on the other hand, postmodern parodic and ironic representational strategies have offered feminist artists an effective way of working within and yet challenging dominant patriarchal metanarrative discourses. That said, there is still noway in which the feminist and the postmodern-as cultural enterprises - can be conflated. The differences are clear, and none so clear as the political one. Chris Weedon opens her recent book on feminist practice ${ }^{11}$ with the words: 'Feminism is a politics.' Postmodernism is not; it is certainly political, but it is politically ambivalent, doubly encoded as both complicity and critique, undermining any fixed metanarrative position. Because of their necessary notion of 'truth,' as Barbara Creed argues, feminisms are not incredulous toward their own metanarrative, even if they do contest the patriarchal one. Feminisms will continue to resist incorporation into postmodernism, largely because of their revolutionary force as political movements working for real social change. They go beyond making ideology explicit and deconstructing it in order to argue a need to change that ideology, to effect a real transformation of art that can only come with a transformation of patriarchal social practices. Postmodernism has not theorized agency; it has no strategies of real resistance that would correspond to the feminist ones. It cannot. This is the price to pay for that incredulity toward metanarrative. 


\section{Notes}

1. Jean-François Lyotard, The Postmodern Condition: A Report on Knowledge, trans. Geoff Bennington and Brian Massumi (Minneapolis: University of Minnesota Press, 1984).

2. Jürgen Habermas, 'Modernity - An Incomplete Project,' trans. Seyla BenHabib, in Hal Foster, ed., The Anti-Aesthetic: Essays on Postmodern Culture (Port Townsend, Wash.: Bay Press, 1983), 3-15.

3. Fredric Jameson, 'Foreword' to Lyotard, vii-xxi.

4. Richard Rorty, 'Habermas, Lyotard et la postmodernité,' Critique, 442 (mars 1984): 181-197.

5. I use the real, if awkward, plural here because there are as many feminisms as there are feminists and no clear cultural consensus in feminist thinking on narrative representation. As Catharine Stimpson has argued ('Nancy Reagan Wears a Hat: Feminism and its Cultural Consensus,' Critical Inquiry, $14,2(1988), 223)$, the history of feminist thought on this topic includes the confrontation of dominant representations of women as misrepresentations, the restoration of the past of women's own self-representation, the generation of accurate representations of women, and the acknowledgement of the need to represent differences among women (of sexuality, race, age, class, ethnicity, nationality), including their diverse political orientations. As a verbal sign of difference and plurality, feminisms would seem to be a useful term to designate, not a consensus, but a multiplicity of points of view which nevertheless do possess at least some common denominators when it comes to the notion of the politics of narrative representation.

6. Roland Barthes, Roland Barthes by Roland Barthes, trans. Richard Howard (New York: Hill \& Wang, 1977), 47.

7. Barbara Creed, 'From Here to Modernity: Feminism and Postmodernism,' Screen 28, 2 (1987), 52.

8. Creed, 67.

9. Victor Burgin, The End of Art Theory: Criticism and Postmodernity (Atlantic Highlands, NJ: Humanities Press International, 1986), 108.

10. Stimpson, 226 .

11. Chris Weedon, Feminist Practice and Poststructuralist Theory (Oxford: Blackwell, 1988). 